\title{
Between Occupation and Politics: Legislative Professionalization in the Swiss Cantons*
}

\author{
Pirmin Bundi ${ }^{+}$ \\ Daniela Eberli ${ }^{\ddagger}$ \\ October 9, 2016 \\ Accepted for publication in the Swiss Political Science Review
}

Sarah Bütikofer§

\begin{abstract}
In this article, we consider the question of how professionalized the cantonal parliamentarians are and which factors are related to this professionalization. By definition, Swiss parliamentarians exert an occupation in parallel to their mandate. We argue that parliamentarians who spend more time for their mandate have more resources to do so and, more importantly, intend to pursue a political career. In doing so, we analyze data gathered from a survey that was conducted among all Swiss cantonal parliaments in 2014. Our multilevel analysis shows that parliamentarians who run for office at the national level spend significantly more time for their parliamentary mandate than their colleagues. This effect decreases with the parliamentarians' age. This finding could be relevant in order to understand the career paths of Swiss parliamentarians. In addition, the study contributes to the discussion of the future development of the militia system in Switzerland.
\end{abstract}

Keywords: Parliament, Professionalization, Militia Parliament, Swiss Cantons, Career Path

\footnotetext{
*A previous version of this article was presented at the Swiss Political Science Association Annual Convention, Basel, January 21-22, 2016. We thank all the participants for their feedback, in particular Pascal Sciarini. Special thanks go to Vanessa Di Giorgi, Gwenyfar Gubler, Mikäel Rédin and Benjamin Schlegel for their excellent research assistance with the parliament survey. We are grateful to Markus Freitag and Adrian Vatter as well as the two anonymous reviewers for their valuable remarks. Finally, we thank the Swiss National Science Foundation for the financial support.

+ Department of Political Science, University of Zurich, Switzerland. Email: bundi@ipz.uzh.ch.

‡ Department of Political Science, University of Zurich, Switzerland. Email: eberli@ipz.uzh.ch.

§ Department of Political Science, University of Zurich, Switzerland. Email: sarah.buetikofer@ipz.uzh.ch.
} 


\section{Introduction}

Parliaments belong to the most elementary institutions of contemporary democracies. They are assigned to represent the electorate, to oversee the government, and to make policies (Blondel 1973; Loewenberg et al. 2002; Martin et al. 2014; Olson and Mezey 1991; Pitkin 1967). Since the activities of most states have increased over time, parliaments face the challenge to be confronted with a higher workload. As a consequence, almost all national parliaments have professionalized in the last decades (Moncrief 1994; Squire 2007; Squire and Moncrief 2015).

The Swiss political system is an exception. The Federal Assembly is still seen as a nonprofessional parliament. This so-called militia system has recently been widely debated in the media and amongst political scientists (Müller 2015; Pilotti et al. 2010; Pilotti 2015). Several studies have investigated the professionalization of the parliaments showing that the members of parliament (MPs) in the Federal Assembly spend increasingly more time for their parliamentary mandate (Bütikofer 2014; Hug et al. 2008; Kerr 1981; Krüger et al. 2001; Riklin and Möckli 1991; Wiesli and Linder 2000; Z'graggen 2009).

In contrast to the development at the national level, most cantonal parliaments still rely on part-time parliamentary mandates and most MPs have a regular occupation next to their parliamentary obligation. Although it is often assumed that cantonal MPs are less professionalized than their colleagues at the federal level, no study has so far systematically investigated the professionalization at the cantonal level. However legislative professionalization has an important impact on the function of the parliament. Several studies from the American states show that the level of professionalization has a high influence on how the parliament works, e.g. power of legislative leaders and re-election strategies (Berry et al. 2000; Clucas 2007; Fiorina 1999; Lax and Phillips 2012).

In this article, we investigate the question of how professionalized the members of the cantonal parliaments are and which factors are related to this professionalization. For this purpose, we consider the amount of time MPs spend exercising their mandate as an indicator of the degree of professionalization at the individual level. We state that the more time an MP dedicates to the parliamentary mandate, the higher is the level of the MP's professionalization. Based on previous research, we argue that MPs with an occupational background that gives them sufficient financial and time resources spend more time for their 
parliamentary mandate. As political experience in local and regional offices is seen as an important stepping-stone to enter a legislative office at the national level (Stolz 2003; Wiesli 1999), we expect that MPs who run for office at the national parliament tend to be more professionalized, since they want to pursue a political career. Indeed, we expect that cantonal particularities also influence the degree of professionalization of the members of cantonal legislatives. For this reason, we analyze the impact of the linguistic region, the size of the cantonal parliament and the allowances of cantonal MPs on their degree of professionalization.

Empirically, the arguments are analyzed with a survey that was conducted among Swiss MPs (Eberli et al. 2014). Among other topics, MPs were asked about their parliamentary work. Our results show that the amount of time spent does not only vary across the MPs, but also between the cantons. The findings suggest that MPs who run for office at the national level spend more time for their parliamentary mandate. This is an important result taking into account that the share of Swiss national MPs who served in a cantonal legislative before entering the national parliament is very high compared to other countries (Bailer 2016; Stolz 2003; Wiesli 1999) and the fact that the Swiss Federal Assembly is characterized by an ongoing process of professionalization. Moreover, our article makes a substantial contribution to the legislative studies by providing a comprehensive analysis for legislative professionalization.

The article is structured as follows: Section 2 defines the concept of legislative professionalization and introduces the hypotheses. Section 3 describes the data and methods, while section 4 illustrates the distribution of legislative professionalization across the Swiss cantons and presents the results of the empirical analysis. Section 5 discusses the results and section 6 concludes.

\section{Legislative Professionalization}

Max Weber's essay "Politics as a Vocation", first published in 1919, launched the debate about politicians and how political mandates should be conducted. In general, the term professionalization describes a transformation process of a specific activity into a profession that respects formal norms and rules of behavior. In the sphere of politics, professionalization is seen as the change from a voluntary engagement to a paid, full-time 
activity, done by elected representatives. This transformation process has consequences not only for the persons holding a political office, but also for the institutions and the political system in its entirety. Thus, it is usual in the political science literature to distinguish between different facets of the process of political professionalization (Squire 1992; Borchert 2003; Z'graggen 2009). Borchert (2003), for example, notes that professionalization can take place at four different levels: those of individuals, offices, institutions, and the political system as such. At the individual level stands the emergence of professional politicians as a new profession. In this context, some authors have for instance analyzed which individuallevel characteristics are more likely to be encountered among professional politicians (Borchert and Golsch 1995). The professionalization of political offices is linked with the amount of resources associated with them, in the form of salary and staff, for example. This is distinct from institutional professionalization, which denotes a similar process at the level of the parliament itself. Finally, system-level professionalization refers to the degree to which various political offices and institutions, at different levels, have gone through such a process.

Being a politician became a regular profession during the last century. Politicians became increasingly dependent on their mandates, as they did not follow other career paths outside of the political sphere. A consequence is that politicians in professionalized parliaments tend to be younger, since they join their party earlier and focus strongly on a career in politics. These MPs also stay longer in office, have a higher degree of education, and the frequency of voluntary demission is decreasing over time (Z'graggen 2009). In highly professionalized institutions, professional politicians follow a typical career path, which is quite similar between different countries and political systems (Stolz 2003). As a consequence, politicians have to possess specific skills that enable them to be successful in their political activity - as other professionals in the private or public sector. Dahl and Lindblom (1953) have early suggested bargaining, negotiation, and the ability to compromise as the most important political skills for a successful career in politics.

Starting in the 1970s, political scientists in Switzerland have developed a growing interest for the professionalization of national MPs. Kerr (1981) conducted a first survey of all members of the Federal Assembly during the $39^{\text {th }}$ legislative period (from 1971 to 1975). Among many other questions, the research team was interested in knowing how much of their working 
time politicians were dedicating to their parliamentary mandate. Surprisingly, only a minority of twenty-five percent of the MPs could be considered as traditional militia politicians (Kerr 1981). Over time, several following surveys confirmed those findings (Riklin and Möckli 1991; Wiesli and Linder 2000: Krüger et al. 2001; Hug et al. 2008): The number of full-time politicians in the Federal Assembly increased over time. These changes had consequences at the organizational level of the Swiss Federal Assembly. The institutions went through several reforms, which also contributed to an increased level of professionalization of both the parliament (Lüthi 1997) and the parliamentary party groups (Bailer and Bütikofer 2015).

The ideal of a militia parliament is still strongly anchored in Swiss society. It is not surprising that several attempts to reform and professionalize the parliament at the national level were declined in the past, with the argument that the militia system guarantees closer links between representatives and the population. Nevertheless, all empirical studies show that MPs with full-time careers outside of politics have become more and more rare at the national level and the number of Swiss MPs who devote a significant part of their working time to politics is increasing. A growing number of MPs dedicate most of their time to politics, or work only for associations, trade unions or in other organizations related to politics (Oesch 2006). But only few MPs actually consider themselves to be full-time politicians. Many MPs still avoid labeling themselves as professional politicians, for instance in their biographical information on the website of the Swiss Parliament (e.g. swissinfo 2014). The argument is that MPs want to keep a strong link to the citizens and avoid becoming isolated from the preferences and problems of their constituencies. Even members of the Council of States who dedicate at least 60 to 70 per cent of their working hours to politics (see, e.g., Hug et al. 2008), did not consider themselves to be fully professional politicians.

In our analysis, we focus on the members of cantonal parliaments. Little is known about cantonal legislators in Switzerland. It is only in recent years that researchers started to focus on the case of cantonal legislators ${ }^{1}$ (e.g. Heinsohn and Freitag 2012; Eberli et al. 2014; Bütikofer and Widmer 2015; Feh Widmer 2015; Feh Widmer and Vatter 2015; Bundi 2016).

\footnotetext{
${ }^{1}$ Feh Widmer (2015) dealt with parliamentary fluctuations in cantonal legislatives; Bundi (2016) and Eberli et al. (2014) investigated evaluation demand and use by legislators, while Bütikofer and Widmer (2015) studied the voting behavior of members of a subnational parliament.
} 
But as far as we know, almost all cantonal legislators can still be considered as part-time politicians. Literally, they keep alive the ideal of the Swiss militia parliament.

\section{Explaining Professionalization in the Swiss Subnational Legislatives}

Our intention is to analyze the situation of the legislative professionalization in all the cantonal legislatures. For this purpose, we draw on the literature on professionalization and research on Swiss parliaments in order to identify factors that are related to the legislative professionalization. We then test these factors with empirical data - to our best knowledge for the first time. As shown before, we define professionalization as the amount of time a MP dedicates to his or her mandate. The amount of time dedicated to the parliamentary work is a direct indicator to measure one's involvement with legislative work. The more working time a MP invests into parliamentary sessions, committee meetings and preparative work, the less time he or she has for pursuing other career paths. Consequently, a large share of working time dedicated to politics implies that the parliamentary mandate can be seen as a full-time job. Therefore, the amount of working time dedicated to the parliamentary mandate seems to be a convincing indicator of professionalization. Indeed, MPs are able to dedicate more time to their elective mandate, if they receive financial compensation and/or can benefit from other material resources to do so (Squire 2007; Z'graggen 2009). Those possible interactions will be taken into account in our analysis.

Firstly, looking at the members of the Federal Assembly, it seems that the occupational background sets favorable conditions for a political mandate at the federal level and consequently for a political career. MPs need to organize their working time in a flexible way. In addition, they should have the financial resources that permit them to pursue a political career. This means, they must allow to investing working time into politics without direct financial compensations - at least at a lower level of a political career. Ideally, these MPs can rely on personal assistants and other staff members. As a consequence, a clear trend has been observed concerning the occupational background of the federal MPs in Switzerland (Bütikofer 2014; Kerr 1981; Riklin and Möckli 1991). As already mentioned, an increasing number of MPs work only in politics related fields (Oesch 2006) and a large share of MPs run their own business (self-employed, large employers or farmers). Selfemployment helps MPs in order to be more independent and thus to spend working time for 
their parliamentary work. Next to these MPs working independently, a considerable share belongs to the category of the so-called socio-cultural professionals; that are employed lawyers, university or high school professors, medical doctors, nurses and journalists. Whilst MPs of this group are less financially independent than self-employed MPs, they are able to spend more time for their parliamentary mandate, since they are often part in less formalized working structures. Drawing on these observations at the federal level, we therefore expect cantonal MPs who have a similar background to that of federal MPs to invest more time in their mandate, as their resources are favorable for a political career. Hence, the following hypotheses are investigated:

H1a: Self-employed MPs are more professionalized than employed MPs.

$H_{1 b:}$ MPs who are part of the group of the socio-cultural professionals are more professionalized than MPs who are part of another group of working logic.

In this regard, we expect therefore that the political ambition is an important factor for the time spent for the mandate. We argue that MPs who want to pursue a political career invest more time for politics, because the parliamentary mandate has a higher significance for those MPs. The aim for and the consequential investment in a political career necessarily somewhat compromises the development of career paths outside politics. Moreover, the MPs who want to pursue a political career are also expected to spend more time for their mandate to have a higher chance of succeeding in their career. In order to be visible to their party colleagues and also to their constituents, they presumably need to invest more time in their mandate. However, we expect the effect of the political ambition to be higher for younger MPs, since the parliamentary mandate is more important for a political career in an early stage of life, while older MPs might have legitimated their career in a different way. A proven indicator for political ambition is whether a cantonal MP aspires to run for office at the national level.

$H_{2 a}$ : MPs who run for office at the national level are more professionalized than MPs who do not run.

$H_{2 b}$ : Younger MPs who run for office at the national level are more professionalized than older MPs who run.

The professionalization of parliaments and politicians also affects the institutions themselves. On the federal level, the Swiss Federal Assembly went through a series of 
reforms in the 1990s. One of the reforms concerned the system of the parliamentary committees (Lüthi 1996, 1997). The former system of ad hoc committees, which were constituted on an ad hoc basis when required for specific bills, has been replaced by a system of standing legislative committees. This reform contributed to an increased level of professionalization not only of the institution of the Swiss Federal Assembly, but of the individual MPs, too (Lüthi 1997; Z'graggen 2009). Another ongoing reform concerns the system of allowances for national level MPs. The principles ruling the financial compensation of MPs changed fundamentally over time. Only a few decades ago, members of the Federal Assembly could rely on small allowances that aimed at covering their travel and accommodation expenses in the capital during the parliamentary sessions. Over time, the Federal Assembly decided within several reforms to raise these allowances (Hasler 1998). Nowadays, Swiss national MPs receive various financial compensations, corresponding both to expenses and to remuneration for their work (Vatter 2014; Bütikofer 2015). It has often been claimed that the individual professionalization of national MPs is related to the more attractive financial conditions associated with the mandate.

At the cantonal level, the allowances are not comparable with those on the national level. While the cantonal parliaments also have undergone reforms and some of the parliaments have introduced systems of annual remuneration, the financial compensation differs widely between the cantons (Lienhard et al. 2011). However, it is interesting to see whether the level of professionalization of cantonal MPs stands in relation with the allowances provided by the different cantonal parliaments. We expect the amount of time dedicated by cantonal MPs to their legislative mandate to be related to the level of their allowances.

$H_{3}: M P$ f from cantons with higher allowances for cantonal legislators are more professionalized than MPs from cantons with lower allowances.

Finally, we will also consider differences between linguistic regions. The linguistic cleavage is one of the best-documented political differences in Switzerland. The German and the Latin parts of the country differ from one another in terms of cultural values and institutional structures (Vatter 2002). Among these differences, one, which has frequently been highlighted, relates to the conception of the role of the state. Citizens in the Latin part of Switzerland tend to have more positive attitudes towards the welfare state. In the Germanspeaking regions, by contrast, the principles of subsidiarity and self-organization are 
considered to be more important (Knüsel 1994). Those different perceptions of the role of the state are also reflected in the importance given to different channels of participation and representation (Bornschier 2015). Elections and representative democracy are central in the Latin cantons. Direct democracy and the direct involvement of citizens in the political process are by contrast given more importance in the German part of Switzerland (Bühlmann et al. 2013). We expect such differences in the relative importance of representative democracy to be reflected in the degree of engagement of MPs.

H4: MPs from cantons in the Latin linguistic part of Switzerland are more professionalized than MPs from the German-speaking cantons.

\section{Data and Methods}

The following analysis is mainly based on data gathered from an online-survey that was conducted in 2014 (Eberli et al. 2014). All the members of the 26 cantonal parliaments were asked to participate in this survey ${ }^{2}$. Among questions concerning other topics, questions concerning the parliamentary work and the individual characteristics of the MPs were included. The following analysis is based on those questions and focuses on the cantonal parliaments.

In total, $56.2 \%$ or 1'458 out of 2'596 cantonal MPs responded to the survey ${ }^{3}$. This response rate is higher than response rates of other, recent surveys with Swiss cantonal MPs. These surveys reached response rates of 21.8\% (Brun and Siegel 2006: 486), 51.4\% (Feh Widmer 2015: 183), and 39.5\% (Strebel 2014: 129), but these rates can only be compared with reservations, since these surveys have covered selected cantons or selected MPs. A response rate of $56.2 \%$ can likewise be considered as comparatively high for elite surveys with MPs on an international comparison (Bailer 2014; Maestas et al. 2003).

As mentioned above, we define the dependent variable as the amount of time a MP dedicates to his or her mandate. More specifically, the MPs were asked to indicate the amount of time spent for their mandate over the last year in percentage of a full-time

2 The members of the Federal Assembly were likewise asked to participate. For an overview of first results from the survey see Eberli et al. (2014: 5ff.). For detailed information about the survey see Bundi et al. (2014).

3 Including the Federal Assembly total 55.3\% responded to the survey. 
employment. In the analysis, we test the hypotheses concerning the occupational background and the candidacy of the national elections. We also include several other control variables on the individual level in our model. Previous research show that female MPs at the federal level in Switzerland tend to invest more time for the parliamentary office than male MPs (Bütikofer 2014). Moreover, the typical career path of future politicians is that they graduate from university and start working in politics or related fields such as think thanks, associations, trade unions, communication or campaigning agencies. MPs usually have a higher level of formal education than the country average (Pilotti et al. 2010). Therefore, the education level of individual MPs is another factor to be taken into account. The dependent and all the independent variables on the individual level are gathered from the survey besides the variable for the candidacy for the elections of the Swiss National Council ${ }^{4}$. In addition, variables on the level of the parliaments are included in the model. We analyze the impact of the linguistic region, the allowances of cantonal MPs per hour of session, and as control variables the size of the cantonal parliament and the competitiveness in the national elections in the respective canton, i.e. the number of candidates per seat available in the National Council. Due to the sample size of 26 cantons, the partly high correlations of the variables and the data quality, it seemed most feasible to focus only on these four variables on the level of the parliaments. These variables have been drawn from diverse sources (Badac 2008; Jaun 2011). A list of all the variables can be found in the Appendix.

The data is analyzed by employing a multi-level model. This seems suitable, on the one hand, since the data has a hierarchical structure with MPs nested in parliaments. It can be expected that the amount of time spent for the mandate varies strongly between the cantonal parliaments, as previous examinations of the cantonal parliaments concerning other characteristics such as session length or allowances suggests (e.g. Bochsler et al. 2004). On the other hand, for the purpose of our analysis variables both on the level of the individual MP and the parliament need to be included in the model. Therefore, a random effects instead of a fixed effects model is preferred. However, the random effects model is controversially discussed due to its assumption of conditional independence between the covariates and

4 The names of the candidates are publicly available: https://www.admin.ch/ch/d/pore/nrw15/list/kt_index.html (13.01.2016). 
group-specific components (Bell and Jones 2015). Put simply, the random-effects model assumes that the effects within a parliament and between parliaments are equal. This might not be the case. E.g. education might have a negative within-effect, as an individual MP works more efficiently and invests less time for the mandate the higher the educational degree, but it might have a positive between-effect, as parliaments with highly educated MPs on average might have a higher workload. In order to relax this assumption, a withinbetween random effects model will be applied. This model separates the effects within $\left(\beta_{1}\right)$ and between groups $\left(\beta_{2}\right)$; i.e. parliaments:

$$
y_{i j}=\beta_{0}+\beta_{1}\left(x_{i j}-\bar{x}_{j}\right)+\beta_{2} \bar{x}_{j}
$$

\section{Findings}

The descriptive analysis shows that the MPs of the cantonal parliaments invest a substantially different amount of time resources for politics. Figure 1 illustrates the distribution of legislative professionalization across the Swiss cantons. In doing so, the figure shows that MPs not only spend a different amount of time for their parliamentary mandate across the cantonal parliaments, but also within the same parliament. However, while MPs in the smaller cantons of Glarus and Appenzell Inner Rhodes dedicate about 7\% of their time for their mandate, the MPs of Zurich, Vaud and particularly Geneva invest more than $30 \%$ for their political profession, which is a considerably higher amount of time. According to Sciarini (2003), the parliament of Geneva is characterized by a particularly high number of sessions. Moreover, the average time varies surprisingly also within a parliament. In particular in Geneva, the invested time ranges between $30 \%$ and $50 \%$. In addition, parliaments often contain to some extent outliers, which invest substantially more time than their colleagues from the same parliament - be it due to the fact they have the possibility to invest more time or because they have to spend more time, since they hold special positions with the parliament. For example in Thurgovia, the average MP spends $15 \%$ for the parliamentary work, but some MPs dedicate $40 \%$ or even $70 \%$ of their time for the same political mandate. 
Figure 1: Legislative Professionalization across the Swiss Cantons ( $n=1377$ )

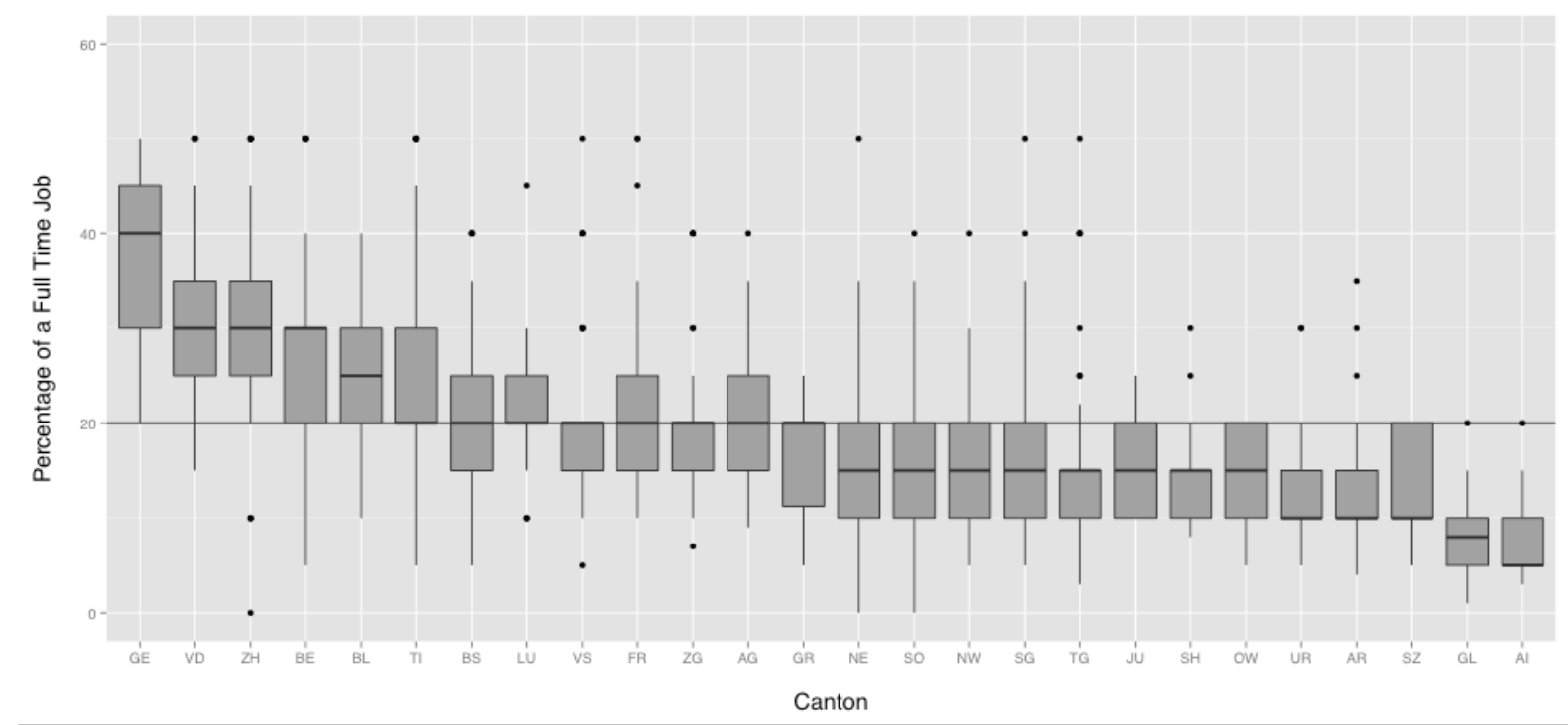

The differences in working time dedicated to the parliamentary mandate exist not only between the various regions in Switzerland, but also between the bigger and smaller cantons. Figure 2 shows that the MPs from the French and Italian part of Switzerland dedicate more time than the parliaments with a German majority. In the center and east of Switzerland, the MPs invest less than one day of their week in their parliamentary mandate, with the exceptions of the cantons of Zurich and Bern. In contrast, in the western part of Switzerland, the MPs invest often substantially more than $20 \%$ of their time for politics. The MPs of Geneva spend almost $40 \%$ of their time for their mandate, but this number is still smaller than at the federal level. However, cantonal MPs need to be prepared to invest between 5\% and $40 \%$ of the time for their mandate, which is a substantial amount of time. In average, a cantonal MP spends around $21 \%$ of a full time job for politics. 
Figure 2: Working time dedicated to the parliamentary mandate across Swiss Cantons (Percentage of a Full-Time Job)

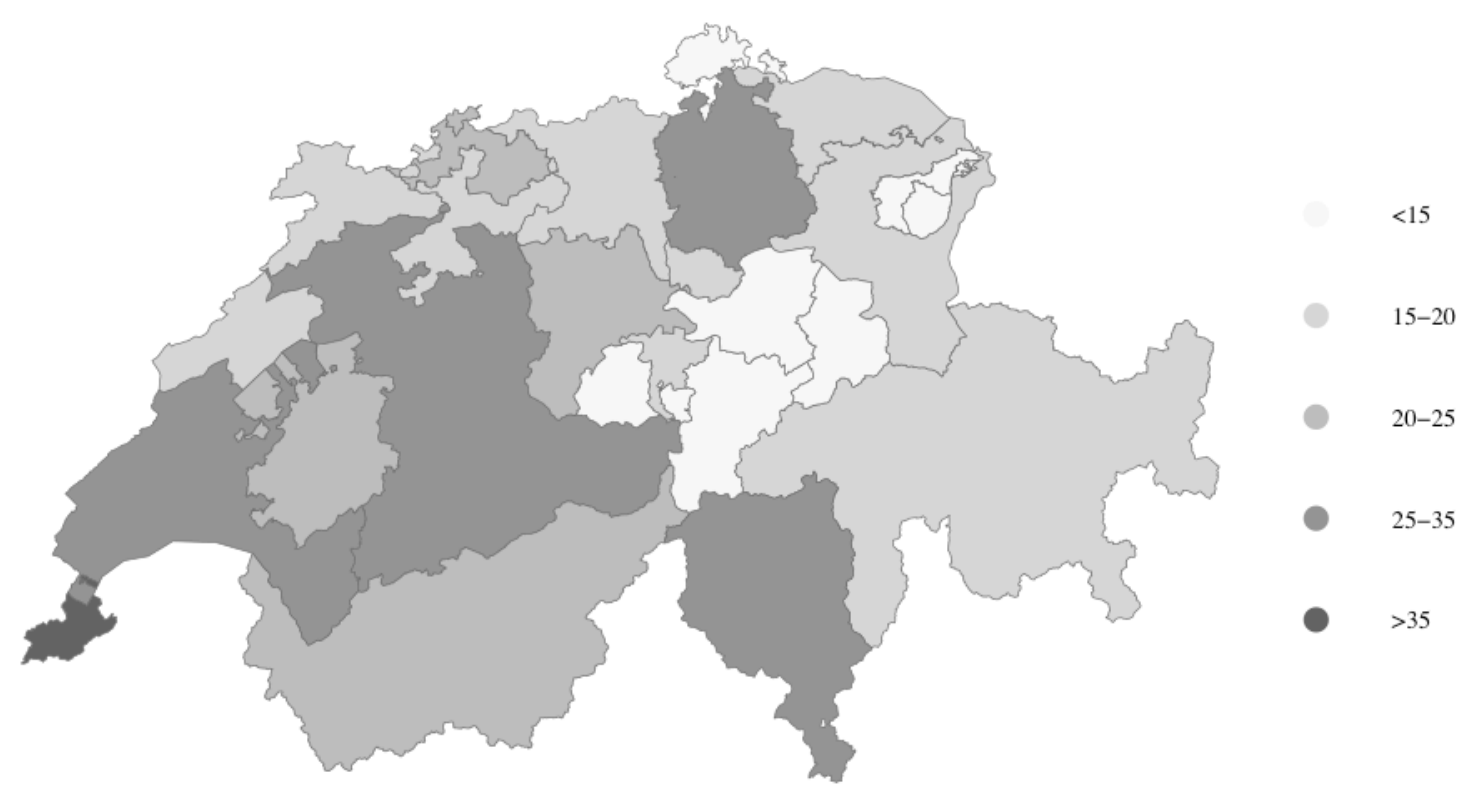

The results for the within-between random effects models in the empirical analysis are illustrated in Table 1. Focusing on the effects within parliaments, firstly, no significant differences for the self-employed are found. In contrast, the respondents belonging to the group of socio-cultural specialists invest significantly less time in their mandate than their counterparts. The coefficient of the within-variable for socio-cultural specialists shows that they invest 1.5 percentage points less in their mandate. Put differently, everything else equal, socio-cultural specialists invest 19.4 percentage, while other respondents invest 20.9 percentage of a full-time employment ${ }^{5}$. Secondly, Table 1 indicates a significant positive effect for candidates within parliaments. This effect diminishes over age - but only in the candidate-specific and not in the full model. These effects concerning candidacy remain unchanged, if a model is estimated that excludes cantons with only one seat in the National Council ${ }^{6}$. An illustration of the effects in the candidate model further provides Figure 3. With respect to a full-time employment, the figure shows that a twenty-year-old candidate invests 7.5 percentage points more time than a non-candidate of his or her age. In percentage of a full-time employment, the responding candidates of 45 years invest 4.7 percentage points

5 Based on model Occupational Background. For modeling interaction terms and marginal effects in withinbetween random effects models see Schunck (2013).

66 cantons have one seat. 
more in their mandate than non-candidates of the same age. While 4.7 per cent of a full-time employment is equal to about two hours per week ${ }^{7}$, this effect is considerable, as the survey showed that on average the respondents invest twenty percent of a full-time employment in total, which corresponds to less than eight and a half hours per week. Confidence intervals included, the effect for candidates is greater than zero until the age of 68 years. Thirdly, concerning the variables on the parliament-level, Table 1 shows a positive significant relationship with the allowances per hours of session. Furthermore, with exception of the full Table 1: Results from the within-between random effects model

\begin{tabular}{|c|c|c|c|c|c|c|c|c|}
\hline \multirow[b]{2}{*}{ Constant } & \multicolumn{6}{|c|}{ Occupational } & \multicolumn{2}{|c|}{ Full Model } \\
\hline & -0.1677 & $(-0.96)$ & -0.1394 & $(-0.99)$ & -0.1482 & $(-0.61)$ & -0.1873 & $(-0.93)$ \\
\hline \multicolumn{9}{|l|}{ Within } \\
\hline Female & $0.0367^{* * *}$ & $(7.03)$ & $0.0366^{* * *}$ & $(7.12)$ & $0.0367^{* * *}$ & $(7.06)$ & $0.0365^{* * *}$ & $(7.12)$ \\
\hline Education & $-0.0022^{*}$ & $(-2.15)$ & -0.0010 & $(-0.93)$ & $-0.0023^{*}$ & $(-2.21)$ & -0.0011 & $(-1.01)$ \\
\hline Age & $0.0009^{* * *}$ & $(3.53)$ & $0.0007^{* *}$ & $(2.75)$ & $0.0013^{* * *}$ & $(4.51)$ & $0.0011^{* * *}$ & $(3.76)$ \\
\hline Self-employed & & & 0.0058 & $(1.07)$ & & & 0.0048 & $(0.90)$ \\
\hline Socio-cultural & & & $-0.0154^{*}$ & $(-2.07)$ & & & $-0.0153^{*}$ & $(-2.06)$ \\
\hline Candidate NC & & & & & $0.0733^{* *}$ & $(2.58)$ & $0.0674^{*}$ & $(2.41)$ \\
\hline Age $x$ Candidate & & & & & $-0.0011^{*}$ & $(-1.99)$ & -0.0010 & $(-1.83)$ \\
\hline \multicolumn{9}{|l|}{ Between } \\
\hline Female & $0.3083^{* * *}$ & $(3.89)$ & $0.1883^{*}$ & $(2.28)$ & $0.3130^{* * *}$ & $(3.93)$ & $0.1957^{*}$ & $(2.35)$ \\
\hline Education & $0.0530^{* * *}$ & $(5.39)$ & $0.0600^{* * *}$ & $(4.24)$ & $0.0560^{* * *}$ & $(4.75)$ & $0.0522^{* *}$ & $(3.27)$ \\
\hline Age & -0.0027 & $(-0.75)$ & -0.0036 & $(-1.17)$ & -0.0034 & $(-0.70)$ & -0.0024 & $(-0.54)$ \\
\hline Self-employed & & & 0.1379 & $(1.83)$ & & & $0.1861^{*}$ & $(2.12)$ \\
\hline Socio-cultural & & & -0.1102 & $(-0.91)$ & & & -0.0859 & $(-0.64)$ \\
\hline Candidate NC & & & & & -0.0856 & $(-0.15)$ & 0.0811 & $(0.14)$ \\
\hline Age $x$ Candidate & & & & & 0.0012 & $(0.10)$ & -0.0030 & $(-0.25)$ \\
\hline Salary MP / hour of session & $0.0006^{* * *}$ & $(5.27)$ & $0.0004^{* * *}$ & $(3.32)$ & $0.0006^{* * *}$ & $(5.27)$ & $0.0004^{* *}$ & $(3.29)$ \\
\hline Latin & $0.0352^{* *}$ & $(2.99)$ & $0.0250^{*}$ & $(2.16)$ & $0.0328^{*}$ & $(2.54)$ & 0.0262 & $(1.94)$ \\
\hline Size parliament & $0.0004^{*}$ & $(2.42)$ & $0.0006^{* * *}$ & $(3.78)$ & 0.0005 & $(1.89)$ & $0.0006^{*}$ & $(2.06)$ \\
\hline Candidates / seat & & & & & -0.0003 & $(-0.29)$ & 0.0013 & $(1.12)$ \\
\hline$\sigma_{\mathrm{u}}$ & $0.0200^{* * *}$ & $(5.28)$ & $0.0192^{* * *}$ & $(5.24)$ & $0.0201^{* * *}$ & $(5.32)$ & $0.0186^{* * *}$ & $(5.19)$ \\
\hline$\sigma_{\mathrm{e}}$ & $0.0830^{* * *}$ & $(49.32)$ & $0.0809^{* * *}$ & $(48.85)$ & $0.0825^{* * *}$ & $(49.32)$ & $0.0805^{* * *}$ & $(48.86)$ \\
\hline $\mathrm{N}$ (parliaments) & 1241 & $(26)$ & 1218 & $(26)$ & 1241 & $(26)$ & 1218 & $(26)$ \\
\hline Log Likelihood & 1310 & .8906 & 1317 & 6501 & 1317 & 6132 & 1324 & .4105 \\
\hline$\varrho$ & 0.0 & 550 & 0.0 & 531 & 0.0 & 558 & 0.0 & 508 \\
\hline
\end{tabular}

Note: coefficients with t-statistics in parentheses, ${ }^{*} \mathrm{p}<0.05,{ }^{* *} \mathrm{p}<0.01,{ }^{* * *} \mathrm{p}<0.001$

model, MPs of cantons fully or partly in the Latin linguistic region spend significantly more time than MPs of cantons in German-speaking cantons. A respondent of a German-speaking canton invests on average 19.7 per cent of a full-time employment in the mandate, while a

7 The Swiss standard full-time employment is 42 hours. 
respondent in a canton fully or partly in the Latin linguistic region spends 2.6 percentage points more, that is 22.3 per cent of a full-time employment. Regarding the control variables, a significant positive relationship is found for female respondents and for age. All else equal, female respondents invest 3.7 percentage points of a full-time employment more in their mandate ${ }^{8}$. MPs also invest significantly more time for their mandate in larger parliaments. Lastly, the number of candidates running for one seat in a canton has no significant effect. This second parliament-level control variable for the competitiveness of the elections is included in the candidate and the full model.

In addition to the within-effects and the variables on the parliament-level, several betweenvariables are significant, particularly gender and education. This can be interpreted that the more female MPs are represented and the higher the education on average in a parliament, the more time MPs spend for their mandate. More importantly, the significant betweeneffects are a sign that the share of women or the educational average correlate with unobser-

Figure 3: Differences for the effect of (non-)candidates over age

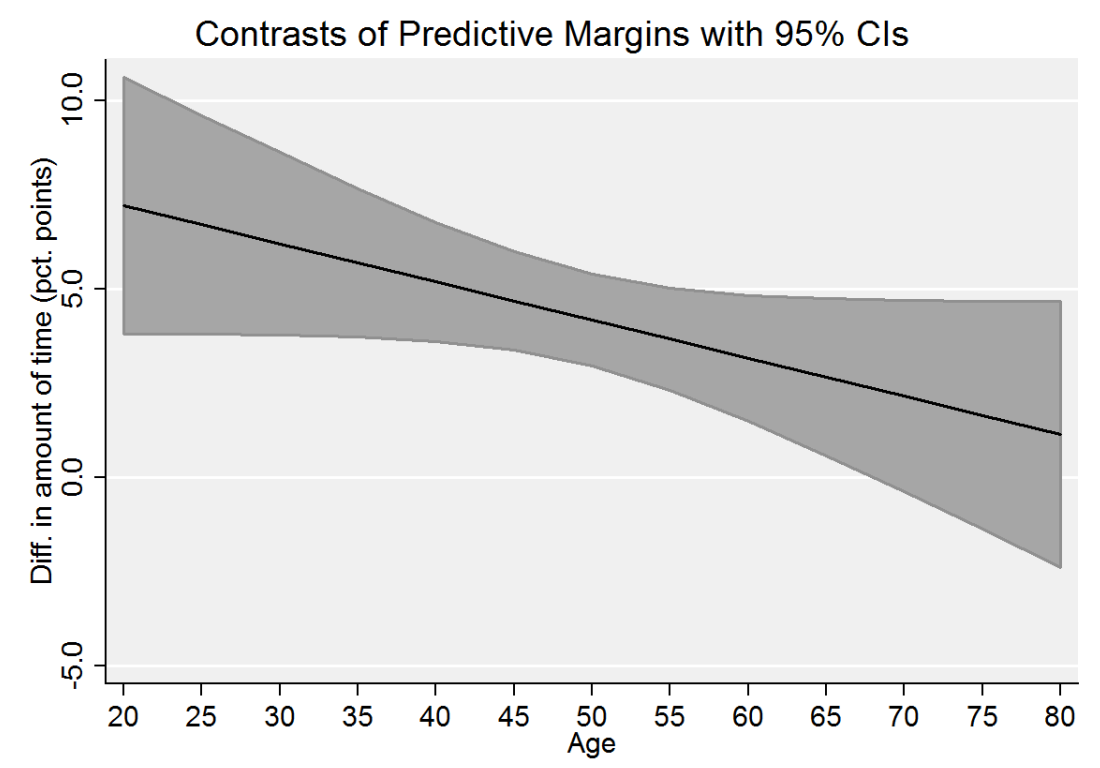

ved variable(s) on the parliament-level effects are a sign that the share of women or the educational average correlate with unobserved variable(s) on the parliament-level, which affect professionalization. Nonetheless, the fit of the model is excellent and a multi-level 
approach with separate within- and between-effects seems indeed necessary, as the significant between-effects imply .

\section{Discussion}

The preceding analysis provided a first comprehensive account of legislative professionalization in the cantons and tested how several individual- or parliament-specific factors mentioned in the literature on professionalization are related to the amount of time spent for the parliamentary mandate in cantons. Two hypotheses on the individual level concerned the MPs' occupational background. As the occupational profile of the national MPs suggests, being able to spend time and resources flexibly seems to be a favorable condition for a political career in Switzerland (Kerr 1981; Riklin and Möckli 1991; Bütikofer 2014). On the one hand, we expected that self-employed MPs invest more time in their mandate $\left(\mathrm{H}_{1 \mathrm{a}}\right)$. However, although $28.9 \%$ of the respondents are self-employed ${ }^{10}$, the analysis did not show a significant difference for self-employed respondents, and the hypothesis has to be rejected. Being self-employed is possibly rather a selection criterion to even start a parliamentary mandate in general and not a criterion for the amount of time spent afterwards. On the other hand, we expected that MPs who are so-called socio-cultural specialists spend more time for their mandate due to their flexible occupations ( $\left.\mathrm{H}_{1 b}\right)$. In the analysis, it was found that socio-cultural specialists spend significantly less time for their mandate than MPs belonging to other groups. This contradicts our hypothesis and can be explained by a closer look at the category of the socio-cultural specialists. Occupations such as physicians, lawyers or professors are considered as socio-cultural specialists (Oesch 2006). These occupations are well represented in the national parliament and probably give the flexibility needed. However, other occupations in the same category possibly set less favorable conditions. A good example is the high-school teachers ${ }^{11}$, which are socio-cultural specialists and well represented on the cantonal, but not on the national level. Consequently,

9 Wald-Tests to test whether the between-effects equal 0 can all be rejected.

10 Overall, about $8 \%$ of the permanent residents in Switzerland are self-employed. http://www.bfs.admin.ch/bfs/portal/de/index/themen/03/02/blank/key/erwerbstaetige0/nach_erwerbsstatus.ht $\mathrm{ml}(13.01 .2016)$

11 In the dataset, $26.67 \%$ of all socio-cultural specialists are teachers in the Cantonal parliament, while $15.38 \%$ of all socio-cultural specialists are teachers in the Federal Assembly. 
although the effect of the socio-cultural specialists is comparatively small in size with 1.5 percentage points, it might be decisive as such occupations constrain the time spent for the mandate already on the cantonal level and then hinder a political career on the national level.

Another two hypotheses on individual factors concerned the political ambitions of the MPs. To consider the parliamentary mandate as a profession does not only mean to be continuously and adequately remunerated, but also to have the possibility to stay in the "profession" and to pursue a career in it (Z'graggen 2009). Therefore, we hypothesized that MPs who want to run for office at the national level invest more time in their mandate than non-candidates $\left(\mathrm{H}_{2 \mathrm{a}}\right)$. Among the candidates, we expected this effect to be stronger for younger candidates, as their occupational career is less developed $\left(\mathrm{H}_{2 b}\right)$. The analysis supports these hypotheses. Even if it is controlled for the number of candidates running for one seat and thus the electoral competitiveness in a canton, candidates for the elections of the National Council in 2015 significantly invest more time in their mandate, whereas the effect is larger for the younger than the older candidates. This latter effect was, however, only significant in the candidate-specific and not in the full model. These findings thus take up the recent work on career paths of MPs, in which one of the groups of MPs is classified as the "young ambitious". This group of MPs distinguishes itself by an early start of the political career and by a very high - and possibly time-consuming - commitment to both their party and political mandate (Bailer et al. 2013).

Concerning parliament-specific factors, we focused on the allowances and the linguistic region as two key variables. Firstly, we hypothesized that the MPs invest the more time in their mandate, the higher they are remunerated $\left(\mathrm{H}_{3}\right)$. This hypothesis is supported, as a significant, but relatively small effect for the allowances for the MPs per hours of session and the time spent for the mandate was found in all the models. Rosenthal (1996) argues that higher compensation attracts more ambitious MPs who devote more time to the mandate. However, the study of Lienhard et al. $(2011,115)$ indicates that the legislative salaries have only a limited influence on the legislative professionalization in Switzerland. According to the authors, the legislative salaries were only cautiously increased in the Swiss cantons due to the restrictions of direct democracy. In contrast, the MPs' devoted time has increased significantly (Kerr, 1981; Riklin and Möckli 1991; Bütikofer 2014). Therefore, we conclude that the compensation for the MPs has only a limited influence on legislative 
professionalization in Switzerland. Secondly, we expected that the MPs in cantonal parliaments fully or partly in the Latin linguistic region invest significantly more time than their counterparts in the German linguistic region. As suggested in the descriptive analysis (see Figure 2), the empirical analysis largely supported this hypothesis. In line with the hypothesis, this finding can be interpreted to capture the different understanding of representation and roles in the Latin vis-à-vis to the German-speaking part of Switzerland (Bühlmann et al. 2013).

The analysis further shows stable effects of the age, which is significantly positively related to the amount spent for the mandate in every model. This effect might be explained, as the age correlates with the experience, and more experienced MPs were previously found to invest more time in their mandate (Bütikofer 2014). However, estimating different models with the variables of age and experience suggested that the explanatory power of age is higher, since experience was not significantly related to the professionalization in most of the models.

The analysis also showed that showed that female respondents invest considerably more time in their mandate than male respondents and thus confirmed previous work (Bütikofer 2014). This finding can be interpreted based on previous work on gender and representation by Fox and Lawless (2011) They found that women have a significantly lower selfassessment of their political skills. This would imply that women spend more time for their mandate, as in their perception, they might feel the need to invest more in order to competently fulfil their mandate. Such an interpretation would mean to even reinforce the underrepresentation of females, as diverse, recent studies come to the conclusion that despite all efforts, women still have more difficulties in combining family life with careers in the job and in politics. For example, Silbermann (2015) stated that the work-life-balance and, as a part of thereof, the combination of family and work contribute to gender differences. Feh Widmer (2015) likewise for the Swiss case found that men more often re-run for office and women stay less long in the cantonal parliaments. Concerning the Swiss local level Plüss and Rusch (2012) state that female MPs resign as they seem often not to have the necessary personal and allowances for their political work. 


\section{Conclusion}

MPs in the Swiss Cantons spend a different amount of time for their parliamentary mandate. To the best of our knowledge, this analysis is the first study that analyzes this aspect of MPs' characteristics and career decisions at the subnational level in Switzerland. This article studied the effect of individual and institutional characteristics on the MPs' professionalization. The analysis shows that the amount of time that MPs dedicate to their mandate varies highly between MPs, albeit cantonal legislatives still have the characteristics of militia parliaments. The findings of our multi-level analysis suggest that the occupational background is less important than the MPs' career ambition: MPs who run for office at the national level are more professionalized than their colleagues who do not want to enter the national legislative. This effect is even more pronounced for younger MPs. Moreover, female MPs are more professionalized as well as MPs in cantons with higher parliamentary allowances.

Some limitations of the study have to be discussed. In literature, professionalization is often described as the transformation in the individual behaviour of an MP or in the attributes of the institutions (Squire 1992). Since we cannot show the dynamics of potential developments over time at the cantonal level due to a lack of data from earlier surveys, we focus on the situation in 2014 when the survey was conducted. Second, different methodological issues may be present in elite studies, such as legislative surveys. A central problem is often selfselection of the participants, which might question the representativeness of the survey (Bundi et al. 2016). This problem seems to be less pronounced, as the response rate of the survey is considerably high: almost six out of ten legislators at the cantonal level answered our questions (56.2\%). Moreover, the distribution of the respondents' characteristics (e.g. party membership, age, language) is similar to that among all invited legislators (Bundi et al. 2014). Third, our measure of professionalization, based only on the amount of time that is spent to fulfill the parliamentary mandate on the individual level, may be seen as imperfect. Borchert (2003) argues that legislative professionalization also takes place at the level of offices, institutions, and the political system as such. Consequently, several studies have included more factors in order to measure professionalization (Squire 1992, 2007). However, building an index in order to measure legislative professionalization has recently been criticized in literature (Bowen and Greene 2014). In doing so, we take the tradition up of 
studies on legislative professionalization in Switzerland (Kerr 1981; Riklin and Möckli 1991; Wiesli and Linder 2000; Krüger et al. 2001; Hug et al. 2008). Moreover, since many factors as personal staff or offices are inexistent in the cantons, reducing professionalization to the dedicated time is reasonable in that context. Due to the fact that slightly more women have participated in the survey and that female legislators tend to invest more time to their mandate in average, the professionalization might have been be slightly overestimated in the survey.

MPs move in mysterious ways. Recent works on legislative careers have tried to understand why MPs run for office (Bailer et al. 2013; Borchert 2011; Fox and Lawless 2011; Hall and Van Houwelling 1995). We have taken another path in order to understand MPs' decision. Our study suggests that more ambitious MPs invest more time for their parliamentary mandate. The implication of this is not only that legislative ambitions are already observable in early stage of a MP's career, but also that subnational MPs take an important role for political careers. Usually, MPs seek to move from the subnational up to the national level (Høyland et al. 2013; Bailer et al. 2013; Bailer 2016). If MPs withdraw from the parliamentary mandate due to their insufficient motivation to invest more time, only MPs with enough time resources will continue to pursue a political career. As a consequence, MPs at the national level will be more professionalized. 


\section{References}

BADAC (2008). EKAV - Schweizer Erhebung über die kantonalen Verwaltungen 2008. http://www.badac.ch/de/enquetes/esac08.php (14.01.2016).

Bailer, S. (2016). Political careers. Public speech, University of Basel, $5^{\text {th }}$ April 2016.

Bailer, S. (2014). Interviews and Surveys in Legislative Research. In Martin, S., T. Saalfeld, and K. Strøm (eds.), The Oxford Handbook of Legislative Studies. Oxford: Oxford University Press, 167-93.

Bailer, S. and S. Bütikofer (2015). From Loose Alliances to Professional Political Players: How Swiss Party Groups Changed. Swiss Political Science Review 21(4): 556-577.

Bailer, S., P. Meissner, T. Ohmura and P. Selb (2013). Seiteneinsteiger im Deutschen Bundestag. Wiesbaden: Springer-Verlag.

Bell, A. and K. Jones (2015). Explaining Fixed Effects: Random Effects Modeling of TimeSeries Cross-Sectional and Panel Data. Political Science Research and Methods 3(1): 133-153.

Berry, W. D., M. B. Berkman and S. Schneiderman. (2000). Legislative professionalization and incumbent reelection: The development of institutional boundaries. American Political Science Review 94(4): 859-874.

Blondel, J. (1973). Comparative Legislatures. Englewood Cliffs: Prentice Hall.

Bochsler, D., C. Koller, P. Sciarini, S. Traimond and I. Trippolini (2004). Die Schweizer Kantone unter der Lupe. Behörden, Personal, Finanzen. Berne: Haupt.

Borchert, J. (2003). Professional Politicians: Towards a Comparative Perspective. In Borchert, J. and J. Zeiss (eds.), The Political Class in Advanced Democracies. Oxford: Oxford University Press, 1-25.

Borchert, J. (2011). Individual ambition and institutional opportunity: a conceptual approach to political careers in multi-level systems. Regional and Federal Studies 21(2): 117-140.

Borchert, J. and L. Golsch (1995). Die politische Klasse in westlichen Demokratien: Rekrutierung, Karriereinteressen und institutioneller Wandel. Politische Vierteljahresschrift 36(4): 609-629.

Bornschier, S. (2015). The New Cultural Conflict, Polarization, and Representation in the Swiss Party System, 1975-2011. Swiss Political Science Review 21(4): 680-701.

Bowen, D. C., and Z. Greene (2014). Should We Measure Professionalization with an Index? A Note on Theory and Practice in State Legislative Professionalization Research. State Politics E Policy Quarterly. 
Brun, M. E. and J. P. Siegel (2006). What Does Appropriate Performance Reporting for Political Decision Makers Require? Empirical Evidence from Switzerland. International Journal of Productivity and Performance Management 55(6): 480-97.

Bühlmann, M., A. Vatter, O. Dlabac and H. P. Schaub (2013). Liberale Romandie, radikale Deutschschweiz? Kantonale Demokratien zwischen Repräsentation und Partizipation. Swiss Political Science Review 19(2): 157-188.

Bütikofer, S. (2015). Fiktion Milizparlament. In Müller, A. (ed.) Bürgerstaat und Staatsbürger. Milizpolitik zwischen Mythos und Moderne. Zürich: Neue Zürcher Zeitung.

Bütikofer, S. (2014). Das Schweizer Parlament. Eine Institution auf dem Pfad der Moderne. BadenBaden: Nomos.

Bütikofer, S. and T. Widmer (2015). Das Abstimmungsverhalten des Zürcher Kantonsrats 20112015. Schlussbericht. Wissenschaftlicher Bericht zu Handen der Parlamentsdienste des Kantons Zürich. Universität Zürich.

Bundi, P. (2016). What Do We Know About the Demand for Evaluation? Insights from the Parliamentary Arena. American Journal of Evaluation. Doi: http://dx.doi.org/10.1177/1098214015621788.

Bundi, P., D. Eberli, K. Frey and T. Widmer (2014). Befragung Parlamente und Evaluationen. Methodenbericht. Universität Zürich.

Bundi, P., F. Varone, R. Gava and T. Widmer (2016). Self-Selection and Misreporting in Legislative Surveys. Political Science Research and Methods. Doi: http://dx.doi.org/10.1017/psrm.2016.35.

Clucas, R. A. (2007). Legislative professionalization and the power of state house leaders. State Politics \& Policy Quarterly 7(1): 1-19.

Dahl R. A. and C. E. Lindblom (1953). Politics, Economics and Welfare. New York: Harper.

Eberli, D., P. Bundi, K. Frey and T. Widmer (2014). Befragung Parlamente und Evaluationen. Ergebnisbericht. Universität Zürich.

Feh Widmer, A. (2015). Parlamentarische Mitgliederfluktuation auf subnationaler Ebene in der Schweiz. Baden-Baden: Nomos.

Feh Widmer, A. and A. Vatter (2015). Institutionelle Regeln oder Politische Kultur? Faktoren der parlamentarischen Mitgliederfluktuation in der Schweiz. Zeitschrift für Parlamentsfragen 46(4): 781-795. 
Fiorina, M. P. (1999). Further Evidence of the Partisan Consequences of Legislative Professionalization. American Journal of Political Science 43(3): 974-977.

Fox, R. L. and J. L. Lawless (2011). Gendered Perceptions and Political Candidacies: A Central Barrier to Women's Equality in Electoral Politics. American Journal of Political Science 55(1): 59-73.

Hall, R. L., and R.P. Van Houweling (1995). Avarice and ambition in Congress: Representatives' decisions to run or retire from the US House. American Political Science Review 89(01): 121-136.

Hasler, T. (1998). Dienen, nicht verdienen, soll das oberste Gebot des Politikers sein. Wie der Staat seine Bundesräte, Nationalräte und Chefbeamten besoldet. Chur: Rüegger.

Heinsohn, T. \& M. Freitag (2012). Institutional foundations of legislative turnover: A comparative analysis of the Swiss cantons. Swiss Political Science Review 18(3): 352-370.

Høyland, B., S. B. Hobolt and S. Hix. (2013). Career Ambitions and Legislative Participation: The Moderating Effect of Electoral Institutions. EUSA 13th Biennial Conference, Baltimore, MD, 2013.

Hug, S., S. Bailer, S. Bütikofer and T. Schulz (2008). Hauptergebnisse Parlamentarierbefragung. SNF-Forschungprojekt Parliamentary Decisions: Electoral considerations, party pressure and strategic calculations. Zürich: Institut für Politikwissenschaft.

Jaun, E. (2011). Die Professionalisierung der Schweizer Kantonsparlamente im Vergleich. Lizentiatsarbeit an der Universität Bern.

Kerr, H. H. (1981). Parlement et société en Suisse. Saint Saphorin: Editions Georgi.

Knüsel, R. (1994). Les minorités ethnolinguistiques autochtones à territoire. L'exemple du cas helvétique. Lausanne: Payot.

Krüger, P., A. M. Schönenberger, M. Derrer and C. Bologna (2001). Entschädigung und Infrastruktur der Parlamentsarbeit. Analytisches Profil über den Wert der parlamentarischen Arbeit. Studie im Auftrag der Staatspolitischen Kommission des Nationalrats. Genf: Eco'Diagnostic.

Lax, J. R., and J. H. Phillips (2012): The democratic deficit in the states. American Journal of Political Science 56(1): 148-166.

Lienhard, A., D. Schwarz, F. Sager, R. Steiner and A. Müller (2011). Reform des Parlamentsrechts im Kanton Bern. Studie im Auftrag der Kommission Parlamentsrechtsrevision des Kantons Bern, Berne: KPM. 
Loewenberg, G., P. Squire and R. D. Kiewiet (2002). Legislatures: Comparative perspectives on representative Assemblies. University of Michigan Press.

Lüthi, R. (1996). Die Wirkung von institutionellen Reformen, dargestellt am Beispiel der Reform der Kommission. Swiss Political Science Review 2(2): 81-111.

Lüthi, R. (1997). Die Legislativkommissionen der Schweizerischen Bundesversammlung. Institutionelle Veränderungen und das Verhalten von Parlamentsmitgliedern. Berne, Stuttgart, Vienna: Haupt.

Maestas, C., G. W. Neeley and L. E. Richardson (2003). The State of Surveying Legislators: Dilemmas and Suggestions. State Politics \& Policy Quarterly 3(1): 90-108.

Martin, S., T. Saalfeld and K. Strøm (2014). The Oxford Handbook of Legislative Studies. Oxford University Press.

Moncrief, G. F. (1994). Professionalization and careerism in Canadian provincial assemblies: Comparison to US state legislatures. Legislative Studies Quarterly 19(1): 33-48.

Müller, A. (2015). Bürgerstaat und Staatsbürger: Milizpolitik zwischen Mythos und Moderne. Zurich: Avenir Suisse und Verlag Neue Zürcher Zeitung.

Oesch, D. (2006). Redrawing the class map. Stratification and institutions in Britain, Germany, Sweden and Switzerland. Basingstoke: New York: Palgrave Macmillan.

Olson, D. M. and M. L. Mezey (1991). Legislatures in the policy process: The dilemmas of economic policy. Cambridge University Press.

Pilotti, A. (2015). The Historical Changes and Continuities of Swiss Parliamentary Recruitment. Swiss Political Science Review 21(2): 246-253.

Pilotti, A., A. Mach and O. Mazzoleni (2010). Les parlementaires suisses entre démocratisation et professionnalisation, 1910-2000. Swiss Political Science Review 16(2): 211245.

Pitkin, H. F. (1967). The concept of representation. Berkeley: University of California Press.

Plüss, L. and M. Rusch (2012). Der Gender Gap in Schweizer Stadtparlamenten. Swiss Political Science Review 18(1): 54-77.

Riklin, A. and S. Möckli (1991). Milizparlament?, in: Parlamentsdienste (Hrsg.). Das Parlament - "Oberste Gewalt des Bundes"? Festschrift der Bundesversammlung zur 700-JahrFeier der Eidgenossenschaft. Berne: Haupt, 145-163.

Rosenthal, A. (1996). State Legislative Development: Observations from three perspectives. Legislative Studies Quarterly 21(2). 169-198. 
Schunck, R. (2013). Within and between estimates in random-effects models: Advantages and drawbacks of correlated random effects and hybrid models. Stata Journal 13(1): 65-76.

Sciarini, P. (2003). Etude de la composition du Grand Conseil du canton de Genève et des conditions dans lesquelles les député-e-s exercent leur mandate. Geneva: Grand Conseil de la République et canton de Genève.

Searing, D. D. (1987). New Roles for Postwar British Politics: Ideologues, Generalists, Specialists, and the Progress of Professionalization in Parliament. Comparative Politics 19 (4): $431-452$.

Silbermann, R. (2015). Gender Roles, Work-Life Balance, and Running for Office. Quarterly Journal of Political Science 10(2): 123-53.

Squire, P. (1992). Legislative professionalization and membership diversity in state legislatures. Legislative Studies Quarterly 17(1). 69-79.

Squire, P. (2007). Measuring State Legislative Professionalization: The Squire Index Revisited. State Politics \& Policy Quarterly 7(2): 211-27.

Squire, P. and G. Moncrief (2015). State legislatures today. Politics under the domes. Lanham: Rowman \& Littlefield.

Stolz, K. (2003). Moving up, Moving down: Political Careers across Territorial Levels. European Journal of Political Research 42(2): 223-48.

Strebel, M. (2014). Exekutivföderalismus in der Schweiz? Einbezug der Parlamente bei interkantonalen Vereinbarungen. Baden-Baden: Nomos.

Swissinfo (2014). Swiss politicians: just don't call me a professional. Online: http://www.swissinfo.ch/directdemocracy/the-militia-system-_swiss-politicians--just-don-tcall-me-a-professional/41065618 [accessed: 15.01.2016].

Vatter, A. (2002). Kantonale Demokratien im Vergleich. Entstehungsgründe, Interaktionen und Wirkungen politischer Institutionen in den Schweizer Kantonen. Opladen: Leske + Budrich.

Vatter, A. (2014). Das politische System der Schweiz. Baden-Baden: Nomos.

Wiesli, R. (1999). Schweiz: Miliz-Mythos und unvollkommene Professionalisierung. In J. Borchert (ed.), Politik als Beruf: Die politische Klasse in westlichen Demokratien. Wiesbaden: VS Verlag für Sozialwissenschaften, 415-438.

Wiesli, R. and W. Linder (2000). Repräsentation, Artikulation und Durchsetzung kantonaler Interessen im Ständerat und Nationalrat. Studie im Auftrag der Parlamentsdienste der Schweizerischen Bundesversammlung. Berne. 
Z'graggen, H. (2009). Die Professionalisierung von Parlamenten im historischen und internationalen Vergleich. Berne: Haupt. 


\section{Appendix}

Table A 1: Description of the variables

\begin{tabular}{|c|c|c|}
\hline \multicolumn{3}{|c|}{ Dependent Variable: Individual Level } \\
\hline Variable & Operationalization & Remark(s) / Source \\
\hline Professionalization & $\begin{array}{l}\text { amount of time dedicated to the parliamentary } \\
\text { mandate in percentage of a full-time } \\
\text { employment, }[0,1], N=1377 \text {, mean }=0.21\end{array}$ & \\
\hline \multicolumn{3}{|c|}{ Independent Variables: Individual Level } \\
\hline Variable & Operationalization & Remark(s) / Source \\
\hline Female & $\begin{array}{l}1=\text { female }(435,29.84 \%) \\
0=\text { male }(1023,70.16 \%)\end{array}$ & \\
\hline Education & $\begin{array}{l}\text { highest educational degree, treated as } \\
\text { continuous variable, }[1,8], \mathrm{N}=1378 \text {, mean }= \\
5.48\end{array}$ & \\
\hline Age & $\begin{array}{l}\text { Age in years }(2014),[21,83], N=1458, \text { mean }= \\
51.51\end{array}$ & \\
\hline Self-employed & $\begin{array}{l}1=\text { self-employed }(373,28.85 \%) \\
0=\text { not self-employed }(920,71.15 \%)\end{array}$ & $\begin{array}{l}\text { based on Oesch (2006), MPs indicating } \\
\text { their occupation as "politician", "mayor", }\end{array}$ \\
\hline Socio & $\begin{array}{l}1=\text { socio-cultural professionals }(165,12.50 \%) \\
0=\text { other categories }(1155,87.50 \%)\end{array}$ & etc. were excluded $(\mathrm{N}=60)$ \\
\hline Candidate NC & $\begin{array}{l}1 \text { = candidate for the elections of the National } \\
\text { Council in } 2015(341,23.39 \%) \\
0=\text { no candidate for the elections of the } \\
\text { National Council in } 2015(1117,76.61 \%)\end{array}$ & $\begin{array}{l}\text { Schweizerische Bundeskanzlei, } \\
\text { https://www.admin.ch/ch/d/pore/nrw15/l } \\
\text { ist/kt_index.html }\end{array}$ \\
\hline \multicolumn{3}{|c|}{$\begin{array}{l}\text { Note that the individual-level variables have been decomposed in two parts: (1) The between variable, which } \\
\text { reflects the parliamentary-specific mean of the variable. (2) The within variable, which reflects the individual } \\
\text { deviation of the parliamentary-specific mean. }\end{array}$} \\
\hline \multicolumn{3}{|c|}{ Parliamentary Level Only } \\
\hline Variable & Operationalization & Remark(s) / Source \\
\hline Latin & $\begin{array}{l}0=\text { German }(17,65.38 \%) \\
1=\text { German and Latin language(s) or only } \\
\text { Latin language }(9,34.62 \%)\end{array}$ & \\
\hline Size Parliament & $\begin{array}{l}\text { Number of seats in the parliament, }[49,180] \\
N=26 \text {, mean }=100\end{array}$ & \\
\hline $\begin{array}{l}\text { Salary MP per hour } \\
\text { of session }\end{array}$ & $\begin{array}{l}\text { Salary per MP in Fr. per hour of session, }[45.55 \text {, } \\
263.72], N=26 \text {, mean }=115.96\end{array}$ & Jaun (2011) \\
\hline Candidates per Seat & $\begin{array}{l}\text { No of (official) Candidates per seat per Canton } \\
\text { in the elections for the National Council in } \\
2015,[2,24.94], N=26 \text {, mean }=14.10\end{array}$ & $\begin{array}{l}\text { Federal Chancellery, } \\
\text { https://www.admin.ch/ch/d/pore/nrw15/1 } \\
\text { ist/kt_index.html }\end{array}$ \\
\hline
\end{tabular}


Table A 2: Overview of legislative professionalization in the Swiss cantons

\begin{tabular}{|c|c|c|c|c|}
\hline Canton & $\begin{array}{c}\varnothing \text { (Time spent in } \\
\text { Percentage of a Full- } \\
\text { Time Employment) }\end{array}$ & Size of Parliament & Salary per MP in CHF & $\begin{array}{c}\text { Candidates per seat in } \\
\text { the elections for } \\
\text { National Council } 2015\end{array}$ \\
\hline $\mathrm{ZH}$ & $30.95 \%$ & 180 & $22^{\prime} 538$ & 24.94 \\
\hline $\mathrm{BE}$ & $27.89 \%$ & 160 & $17^{\prime} 061$ & 22.68 \\
\hline LU & $22.66 \%$ & 120 & $10^{\prime} 195$ & 15.90 \\
\hline UR & $13.25 \%$ & 64 & $4^{\prime} 425$ & 3.00 \\
\hline SZ & $13.12 \%$ & 100 & $5^{\prime} 241$ & 12.50 \\
\hline OW & $13.75 \%$ & 55 & $4^{\prime} 155$ & 2.00 \\
\hline NW & $16.09 \%$ & 60 & $5^{\prime} 811$ & 2.00 \\
\hline GL & $7.97 \%$ & 60 & $2^{\prime} 900$ & 2.00 \\
\hline ZG & $19.92 \%$ & 80 & $9^{\prime} 801$ & 16.67 \\
\hline FR & $21.04 \%$ & 110 & $10^{\prime} 162$ & 18.71 \\
\hline SO & $17.32 \%$ & 100 & $8^{\prime} 900$ & 24.50 \\
\hline BS & $22.75 \%$ & 100 & $15^{\prime} 294$ & 24.40 \\
\hline BL & $24.27 \%$ & 90 & $14^{\prime} 413$ & 16.00 \\
\hline $\mathrm{SH}$ & $14.47 \%$ & 60 & $6^{\prime} 682$ & 10.50 \\
\hline $\mathrm{AR}$ & $13.17 \%$ & 65 & $4^{\prime} 574$ & 3.00 \\
\hline AI & $7.27 \%$ & 49 & $1^{\prime} 481$ & 2.00 \\
\hline SG & $16.02 \%$ & 120 & $12^{\prime} 840$ & 16.50 \\
\hline GR & $17.67 \%$ & 120 & $14^{\prime} 627$ & 14.00 \\
\hline AG & $19.60 \%$ & 140 & $11^{\prime} 597$ & 18.00 \\
\hline TG & $15.62 \%$ & 130 & $7^{\prime} 051$ & 20.50 \\
\hline $\mathrm{TI}$ & $27.33 \%$ & 90 & $25^{\prime} 653$ & 15.25 \\
\hline VD & $31.18 \%$ & 150 & $27^{\prime} 125$ & 18.11 \\
\hline VS & $21.16 \%$ & 130 & $12^{\prime} 235$ & 21.63 \\
\hline NE & $17.80 \%$ & 115 & $5^{\prime} 238$ & 13.50 \\
\hline GE & $37.45 \%$ & 100 & $37^{\prime} 448$ & 16.18 \\
\hline $\mathrm{JU}$ & $15.44 \%$ & 60 & $12^{\prime} 875$ & 12.00 \\
\hline Mean & $19.43 \%$ & 100 & $11^{\prime} 935$ & 14.10 \\
\hline
\end{tabular}

Source: Badac, 2008; Eberli et al., 2014; Jaun, 2011, Federal Chancellery,

https://www.admin.ch/ch/d/pore/nrw15/list/kt_index.html 
Pirmin Bundi is a Ph.D. candidate at the University of Zurich and currently a visiting graduate researcher at the University of California, Los Angeles. His research focuses on policy evaluation and legislative behavior. Other interests include survey methodology and comparative public policy. Address for correspondence: Department of Political Science, University of Zurich Affolternstrasse 56, CH-8050 Zurich, Switzerland Tel: +41 4463439 98; Email: bundi@ipz.uzh.ch.

Daniela Eberli is a Ph.D. candidate at the University of Zurich. Her research interests include the use of policy evaluations or knowledge in general and legislative behavior. Address for correspondence: Department of Political Science, University of Zurich, Affolternstrasse 56, CH8050 Zurich, Switzerland, Phone: +41 446345842 ; Email: eberli@ipz.uzh.ch.

Sarah Bütikofer is a political scientist at the University of Zurich and editor of the political and social science knowledge transfer platform DeFacto. Her research focuses mainly on legislative behavior and Swiss politics, and she has a special interest in scientific journalism and communication. Address for correspondence: Department of Political Science, University of Zurich Affolternstrasse 56, CH-8050 Zurich, Switzerland Tel: +41 4463454 11; Email: sarah.buetikofer@ipz.uzh.ch. 